\title{
Transformation of Xanthomonas axonopodis pv. citri by Electroporation
}

\author{
Alexandre M. do Amaral ${ }^{1,2}$, Cristiane P. Toledo ${ }^{2}$, Juliana C. Baptista ${ }^{2}$ \& Marcos A. Machado $^{2}$ \\ 1EMBRAPA Recursos Genéticos e Biotecnologia, aamaral@cenargen.embrapa.br; ²Centro APTA Citros "Sylvio Moreira", \\ Rod. Anhangüera, km 158, Cx. Postal 4, Cordeirópolis, SP, CEP 13490-970, fax (019) 3546-1399
}

(Accepted for publication on 28/06/2004)

Corresponding author: Alexandre Morais do Amaral

DO AMARAL, A.M., TOLEDO, C.P., BAPTISTA, J.C. \& MACHADO, M.A. Transformation of Xanthomonas axonopodis pv. citri by electroporation. Fitopatologia Brasileira 30:292-294. 2005.

\begin{abstract}
This study describes the use of electroporation for transforming Xanthomonas axonopodis pv. citri (Xac), the causal agent of citrus (Citrus spp.) canker. It also evaluates the methodology used for this species under different electrical parameters. The bacterium used in the study (Xac 306) was the same strain used for recent complete sequencing of the organism. The use of a plasmid (pUFR047, gentamycin ${ }^{r}$ ) is reported here to be able to replicate in cells of Xac. Following the preparation and resuspension of competent cells of Xac at a density of $\sim 4 \times 10^{10} \mathrm{cfu} / \mathrm{ml}$, in $10 \%$ glycerol, and the addition of the replicative plasmid, an electrical pulse was applied to each treatment. Selection of transformants showed a high efficiency of transformation ( $1.1 \times 10^{6}$ transformants/ $\mu \mathrm{g}$ DNA), which indicates an effective, and inverse, combination between electrical resistance (50 $\Omega$ ) and capacitance $(50 \mu \mathrm{F})$ for this species, with an electrical field strength of $12.5 \mathrm{kV} \cdot \mathrm{cm}^{-1}$ and 2.7 -ms pulse duration. Besides the description of a method for electroporation of Xac 306, this study provides additional information for the use of the technique on studies for production of mutants of this species.
\end{abstract}

Additional key words: citrus canker, mutant, Citrus spp.

RESUMO

Transformação de Xanthomonas axonopodis pv. citri através de eletroporação

É descrito o uso da eletroporação para a transformação de Xanthomonas axonopodis pv. citri (Xac), a agente causal do cancro cítrico, e a avaliação da metodologia para esta espécie sob diferentes parâmetros elétricos. A bactéria utilizada neste estudo (Xac 306) foi a mesma isolado usado recentemente no seqüenciamento completo do organismo. Aqui, é documentado o uso do plasmídeo pUFR047 (gentamicinar) capaz de replicar em células de Xac. Após a preparação e re-suspensão das células competentes de Xac na densidade de $\sim 4 \times 10^{10} \mathrm{ufc} / \mathrm{ml}$, em $10 \%$ glycerol, e a adição do plasmídeo replicativo, um pulso elétrico foi aplicado a cada tratamento. A seleção dos transformantes mostrou uma alta eficiência de transformação (1,1 x $10^{6}$ transformantes/ $\mu$ g DNA), o que indica uma efetiva e inversa combinação entre a resistência elétrica $(50 \Omega)$ e a capacitância $(50 \mu \mathrm{F})$ para esta espécie, com uma descarga elétrica de $12.5 \mathrm{kV} . \mathrm{cm}^{-1}$ e duração de pulso de $2,7 \mathrm{~ms}$. Além da descrição de método de eletroporação do isolado Xac 306, este estudo fornece informação adicional para o uso da técnica em estudos para a produção de mutantes da espécie.

Palavras-chave adicionais: cancro cítrico, mutante, Citrus spp.

Methods that facilitate the functional analysis of the genome are essential for studies of the molecular interaction between microorganisms and the host plant. After the complete sequencing of various plant pathogenic bacteria, including the causal agent of the citrus (Citrus spp.) canker, Xanthomonas axonopodis pv. citri (Xac) (da Silva et al., 2002), protocols of such techniques have been even more necessary.

In general, the inactivation of a certain protein by the disruption of its gene, i.e., the production of a mutant, is the main approach taken to initiate the study of its function (Dorsey et al., 2002; Serror et al., 2002). Taking into consideration that there will be no expression of the truncated gene in the organism, it is possible to evaluate, at least partially, the consequences of a functional gene (protein) for the survival of a pathogen and/or its capacity to colonize the host plant. However, for such inactivation to take place, the first step is for a modified DNA harboring a fragment of the gene ("construct") to enter the bacterial cell.

Moreover, many reports have been published recently with the use of the technique to produce mutants of bacteria, including plant pathogens (Guilhabert et al., 2001; Monteiro et al., 2001; Serror et al., 2002; Brumbley et al., 2002). Although the causal agent of citrus canker is one of the most economically important plant pathogens worldwide, there is no available literature on the electro transformation of the pathovar so far (Yang et al., 1991; Shaw \& Khan, 1993; White \& Gonzalez, 1995; Tung \& Kuo, 1999). This indicates that the bacterium that causes citrus canker lacks either a description of the methodology used for transformation by electroporation or that the species shows a low level of response to electroporation. 
Based on the fact that many species within the genus Xanthomonas are electro-competents (White \& Gonzalez, 1991; Mongkolsuk et al., 1996; Mongkolsuk et al., 1998), the bacterium $X a c$ is supposedly able to be transformed by electroporation. This, however, remains to be determined through a reliable protocol.

The present report describes a simple and reliable protocol for the transformation of Xac by using a method that comprises the preparation of competent cells, the electrical pulse, and selection of transformants.

\section{Preparation of competent cells}

A small amount of the bacterium Xac 306, the same strain used for the complete genome sequencing (Da Silva et al., 2002), was collected with wire loop from a $-70{ }^{\circ} \mathrm{C}$ stock culture (stored in $15 \%$ glycerol) and spread onto culture plates with NYG medium (5 $\mathrm{g}$ of peptone, $3 \mathrm{~g}$ of yeast extract, and $20 \mathrm{~g}$ of glycerol per liter), without antibiotics. The plates were incubated during $48 \mathrm{~h}$ at $28{ }^{\circ} \mathrm{C}$. Xac colonies were scraped from plates and transferred to a $500-\mathrm{ml}$ tube containing $200 \mathrm{ml}$ of NB medium ( $8 \mathrm{~g}$ of nutrient broth and $5 \mathrm{~g}$ of $\mathrm{NaCl}$ per liter, $\mathrm{pH}$ 7.0) for growth under rotary shaking $(140 \mathrm{rpm})$ at $28^{\circ} \mathrm{C}$ during approximately $4 \mathrm{~h}$.

Following growth in liquid medium until $\mathrm{OD}_{600}=0.6$ [approximately $10^{6}$ colony-forming units (cfu) per ml], which corresponds to the midlog-growth phase, bacterial cells were kept on ice during $1 \mathrm{~h}$. Then, the cells were harvested and washed by centrifugation steps $(4000 \mathrm{xg})$, for $10 \mathrm{~min}$, at $4{ }^{\circ} \mathrm{C}$ with resuspension in 1 and 0.5 volumes of $10 \%$ cold sterile glycerol. The last washing was performed by addition of 1 $\mathrm{ml}$ of $10 \%$ cold sterile glycerol and centrifugation at 13,000 $\mathrm{xg}$, during $2 \mathrm{~min}$ and at $4{ }^{\circ} \mathrm{C}$. The supernatant was partially removed to allow enough liquid for resuspension of the bacterial cells and a final concentration of $4 \times 10^{10} \mathrm{cfu} / \mathrm{ml}$. Finally, the resulting competent cells were held on ice until the transformation (1-2 h).

\section{Preparation of replicative plasmid}

The replicative plasmid pUFR047 (De Feyter et al., 1993) used for this study is $8.6 \mathrm{~kb}$ in size, has the replication origin of plasmid Sa (IncW replicon), and carries genes for resistance to ampicillin and gentamycin. The plasmid was transformed into Escherichia coli and purified by using QIAGEN Plasmid Mini Kit (Qiagen, Valencia, USA).

A $3-\mu \mathrm{l}$ aliquot of the plasmid suspension $(30 \mathrm{ng} / \mu \mathrm{l})$ was mixed to $40 \mu \mathrm{l}$ of the electro competent cells then transferred to a pre-chilled, sterile electroporation chamber (BIO-RAD, Hercules, USA) with 2-mm gap.

\section{Electroporation and selection}

A single high-voltage pulse was applied to each treatment, which was represented by the combination between resistance $(50,100,200$, and $600 \Omega$ ) and capacitance (50, 25,10 , and $3 \mu \mathrm{F}$ ). The resulting pulse duration was the response of those two parameters. Each sample was submitted to the same electric field strength $\left(12.5 \mathrm{kV} \cdot \mathrm{cm}^{-1}\right)$. Following the pulse, $1 \mathrm{ml}$ of NBY medium [0.8\% nutrient broth (Difco, Erembodegem, Belgium), $0.2 \%$ yeast extract, $0.2 \% \mathrm{~K}_{2} \mathrm{HPO}_{4}$, $0.05 \% \mathrm{KH}_{2} \mathrm{PO}_{4}, 0.25 \%$ glucose] supplemented with $20 \mathrm{ml}$ of glucose $(10 \%)$ and $1 \mathrm{ml}$ of $1 \mathrm{M} \mathrm{MgSO}_{4}$ per liter, without antibiotics, was immediately added to the cells. Then, the suspension was transferred to a tube and placed in a rotary shaker (140 rpm), at $28{ }^{\circ} \mathrm{C}$ for $1 \mathrm{~h}$, to allow expression of antibiotic resistance. After incubation, the cells were selected on plates with Nutrient Agar ( $3 \mathrm{~g}$ beef extract, $5 \mathrm{~g}$ peptone, 8 $\mathrm{g}$ sodium chloride and $15 \mathrm{~g}$ agar per liter) supplemented with gentamycin $(5 \mu \mathrm{g} / \mathrm{ml})$. Plates with $\mathrm{Xac}$ were placed at $28^{\circ} \mathrm{C}$ during 48-72 $\mathrm{h}$ for selection of transformants. The assay was replicated three times.

Time of pulse is a result of the combination between resistance and capacitance parameters applied to Xac cells (Table 1). Accordingly, there was a reasonable ratio between the two parameters to allow an optimum rate of transformation and avoid arcing of samples, which is one of the main sources of failure in recovering transformed cells. In general, the best results for transformation of Xac 306 were obtained using low levels of resistance $(50 \Omega)$ and capacitance $(50 \mu \mathrm{F})$, whose values are quite different from those used for maximum transformation efficiency of Xylella fastidiosa Wells ( $4 \Omega$ and $300 \mu \mathrm{F}$ ) (Guilhabert et al., 2001), although both experiments had different objectives. In general, there was an average of frequency (transformants/survivors) of nearly $2.5 \times 10^{-6}$.

It is noteworthy that both, the species and the strain of most bacteria, influence over their capacity of being transformed (Guilhabert et al., 2001; Brumbley et al., 2002). For instance, $X$. fastidiosa, the causal agent of citrus variegated chlorosis (CVC), shows a considerable variation among isolates for transformation by electroporation. Actually, some important strains, such as the strain used for the complete genome sequencing, have shown no competence for transformation by electroporation so far. Other strains of the same bacterium, however, are electro-transformable (Monteiro et al., 2001).

In fact, in Xanthomonas spp., a wide range of responses to electroporation is expected according to the strain (White \& Gonzalez, 1991), which indicates that the isolate has to be taken into consideration when use of the transformation technique is intended.

TABLE 1 - Electroporation parameters used for transformation of competent cells of Xanthomonas axonopodis pv. citri with the replicative plasmid pUFR047

\begin{tabular}{ccccc}
\hline \hline Treatment & $\begin{array}{c}\text { Resistance } \\
(\Omega)\end{array}$ & $\begin{array}{c}\text { Capacitance } \\
(\mu \mathrm{F})\end{array}$ & $\begin{array}{c}\text { Time } \\
(\mathrm{ms})\end{array}$ & $\begin{array}{c}\text { Efficiency }^{1} \\
(\text { transformants/ } \mu \mathrm{g} \text { DNA) }\end{array}$ \\
\hline 1 & 50 & 50 & 2.66 & $1.1 \times 10^{6}$ \\
2 & 100 & 25 & 2.54 & $9.8 \times 10^{5}$ \\
3 & 200 & 10 & 1.90 & $2.1 \times 10^{5}$ \\
4 & 600 & 3 & 1.82 & $5.8 \times 10^{5}$ \\
\hline
\end{tabular}

${ }^{1}$ Each value of transformation efficiency corresponds to the highest value found in each treatment. 
The intermediate efficiency identified in $X a c$ for transformation when compared to other xanthomonads may be a result of various aspects of its biology, besides the strain per se. For instance, the high content of polysaccharides present in cells, which is related to the species as well as to the growth phase, is a critical component for the success of electrical shock (Murooka et al., 1987). Other aspects to be taken into account for the rate of transformation of $\mathrm{Xac}$ are the preparation of competent cells and the recovery of transformants. Although they are obviously variable for different species of xanthomonads, it is an open question if modifications in the protocols used in this study may somehow optimize the technique. In future assays, more isolates could be added in studies that aim to verify optimum conditions for this same species.

However, as a first approach for the transformation of Xac 306 by electroporation, the methodology and the parameters used in this study show that this technique can serve in studies that emphasize the genetics and the mutational analysis of this bacterium. Furthermore, this tool can help in using the enormous amount of data from the complete genome of the causal agent of citrus canker.

\section{ACKNOWLEDGEMENTS}

We wish to thank Ricardo Harakava, on behalf of Dean W. Gabriel, for providing the replicative plasmid pUFR047.

\section{LITERATURE CITED}

BRUMBLEY, S.M., PETRASOVITS, L.A., BIRCH, R.G. \& TAYLOR, P.W.J. Transformation and transposon mutagenesis of Leifsonia xyli subsp. xyli, causal organism of ratoon stunting disease of sugarcane. Molecular Plant-Microbe Interaction 15:262268. 2002.

Da SILVA, A.C.R et al. Comparison of the genomes of two Xanthomonas pathogens with differing host specificities. Nature 417:459-463. 2002.

De FEYTER, R., YAN, Y. \& GABRIEL, D.W. Gene for genes interactions between cotton $\mathrm{R}$ genes and Xanthomonas campestris pv. malvacearum avr genes. Molecular Plant-Microbe Interaction 6:225-237. 1993.

DORSEY, C.W., TOMARAS, A.P. \& ACTIS, L.A. Genetic and phenotypic analysis of Acinetobacter baumannii insertion derivatives generated with a transposome system. Applied and Environmental Microbiology 68:6353-6360. 2002.

GUILHABERT, M.R., HOFFMAN, L.M., MILLS, D.A. \& KIRKPATRICK, B.C. Transposon mutagenesis of Xylella fastidiosa by electroporation of $\mathrm{Tn} 5$ synaptic complexes Molecular PlantMicrobe Interaction 14:701-706. 2001.

MONGKOLSUK, S., LOPRASERT, S., VATTANAVIBOON, P., CHANVANICHAYACHAI, C., CHAMNONGPOL, S. \& SUPSAMRAN, N. Heterologous growth phase- and temperaturedependent expression and $\mathrm{H}_{2} \mathrm{O}_{2}$ toxicity protection of a superoxideinducible monofunctional catalase gene from Xanthomonas oryzae pv. oryzae. Journal of Bacteriology 178:3578-3584. 1996.

MONGKOLSUK, S., SUKCHAWALIT, R., LOPRASERT, S., PRAITUAN, W. \& UPAICHIT, A. Construction and physiological analysis of a Xanthomonas mutant to examine the role of the $\operatorname{xyy} R$ gene in oxidant-induced protection against peroxide killing. Journal of Bacteriology 180:3988-3991. 1998.

MONTEIRO, P.B., TEIXEIRA, D.C., PALMA, R. R., GARNIER, M., BOVÉ, J.M. \& RENAUDIN, J. Stable transformation of the Xylella fastidiosa citrus variegated chlorosis strain with oriC plasmids. Applied and Environmental Microbiology 67:2263-2269. 2001.

MUROOKA, Y., IWAMOTO, H., НАMAMOTO, A. \& YAMAUCHI, T. Efficient transformation of phytopathogenic strains of Xanthomonas species. Journal of Bacteriology 169:4406-4409. 1987.

SERROR, P., SASAKI, T., DUSKO EHRLICH, S. \& MAGUIN, E. Electrotransformation of Lactobacillus delbrueckii subsp. bulgaricus and L. delbrueckii subsp. lactis with various plasmids. Applied and Environmental Microbiology 68:46-52. 2002.

SHAW, J.J. \& KHAN, I. Efficient transposon mutagenesis of Xanthomonas campestris pv. campestris by high-voltage electroporation. Biotechniques 14:556-558. 1993.

TUNG, S.Y. \& KUO, T.T. Requirement for phosphoglucose isomerase of Xanthomonas campestris in pathogenesis of citrus canker. Applied and Environmental Microbiology 65:5564-5570. 1999.

WHITE, T.J. \& GONZALEZ, C.F. Application of electroporation for efficient transformation of Xanthomonas campestris pv. oryzae. Phytopathology 81:521-524. 1991.

WHITE, T.J. \& GONZALEZ, C.F. Electroporation of Xanthomonas. Methods in Molecular Biology 47:135-141. 1995.

YANG, M.K., SU, W.C. \& KUO, T.T. Highly effecient transfection of Xanthomonas campestris by electroporation. Botanical Bulletin of Academia Sinica 32:197-203. 1991. 